\title{
The Effects of Growth Factors on the Survival and Differentiation of Cultured Dentate Gyrus Neurons
}

\author{
Daniel H. Lowenstein ${ }^{1,2,3}$ and Lynn Arsenault1 \\ Departments of ${ }^{1}$ Neurology and ${ }^{2}$ Anatomy, and ${ }^{3}$ Program in Neuroscience, University of California, \\ San Francisco, California 94143
}

\begin{abstract}
Dentate granule cells (DGCs) are the principal cell population of the hippocampal dentate gyrus, and granule cells provide the main excitation to the hippocampus proper via their mossy fibers axons. Although it is well established that granule cells express various growth factors and growth factor receptors, the functional effects of growth factors on the normal development and response to injury of granule cells are relatively unknown. To address this question, primary cultures enriched in DGCs were prepared by microdissecting hippocampal slices from neonatal rats and growing dissociated cells in defined media with added nerve growth factor, brain-derived neurotrophic factor (BDNF), neurotrophin-3 (NT-3), neurotrophin-4/5 (NT4/5), ciliary neurotrophic factor, basic fibroblast growth factor (bFGF), or vehicle. The effects on cell survival and morphology were quantified by studying neuron-specific enolaseimmunostained cells at various time points, plating densities, host ages, and growth factor concentrations. BDNF or bFGF significantly increased both neuronal survival and differentiation by $30-80 \%$ compared with control cultures. Maximal effects were observed at relatively longer time points (5-12 d), with younger cells (postnatal day 3-5) and at lowest plating densi-
\end{abstract}

ties. Addition of a trkB-lgG fusion protein that blocks the activity of BDNF or NT4/5 inhibited the effects of BDNF and attenuated the differentiation of cells cultured at high plating densities. Furthermore, treatment of cultures with the kinase inhibitor K252b specifically blocked the effects of BDNF, suggesting involvement of trkB (the high-affinity BDNF receptor) in BDNF-induced differentiation. These results show that growth properties of cultured neonatal DGCs are influenced by exogenously applied BDNF or bFGF in a time-, age-, and densitydependent manner. The effect of plating density suggests an endogenous expression of growth factors in these culture conditions, and this is mediated in part by endogenous BDNF acting via a tyrosine kinase receptor. Combined with previous work showing that various growth factors and their receptors are expressed by DGCs, these findings provide strong support for the hypothesis that BDNF and bFGF influence both the growth and development of DGCs in vivo.

Key words: neurotrophins; growth factors; brain-derived neurotrophic factor; basic fibroblast growth factor; tyrosine kinase receptors; hippocampus; dentate gyrus; plasticity
The granule cells of the dentate gyrus (DGCs) are a critical component of the pathway that relays information from the entorhinal cortex to the hippocampus proper. Although the functions of the dentate gyrus remain uncertain, it appears that DGCs have an important role in visual-spatial learning and memory (Armstrong et al., 1993; Conrad and Roy, 1993; Vaher et al., 1994), and they are capable of a high degree of functional plasticity. This includes electrophysiological plasticity such as longterm potentiation and long-term depression (Malenka and Nicoll, 1993; Malenka, 1995), and morphological plasticity such as the modification of axo-dendritic contacts following certain stimulation paradigms (Gomez et al., 1990).

In addition to the functional plasticity found under normal conditions, DGCs are also capable of dramatic morphological plasticity in the setting of injury. This is best exemplified by the prominent reorganization of dentate granule cell axons (i.e., mossy fibers) seen in humans with temporal lobe epilepsy and in

\footnotetext{
Received Aug. 30, 1995; revised Dec. 1, 1995; accepted Dec. 6, 1995.

We thank Drs. Helen Scharfman and Robert Sloviter for many useful discussions and critical review of this manuscript, and we thank David Shelton from Genentech for providing the trk-IgG fusion proteins. These studies were supported by grants to D.H.L. from National Institutes of Health (NS32062) and the Esther A. and Joseph Klingenstein Fund.

Correspondence should be addressed to Dr. Daniel H. Lowenstein, Department of Neurology, P.O. Box 0114, University of California, San Francisco, CA 94143 Copyright (C) 1996 Society for Neuroscience $0270-6474 / 96 / 161759-11 \$ 05.00 / 0$
}

various animal models (Laurberg and Zimmer, 1981; Tauck and Nadler, 1985; Cronin and Dudek, 1988; Sutula et al., 1988; Isokawa et al., 1993; Mello et al., 1993). Normally, the mossy fibers synapse primarily with neurons in the dentate hilus and CA3 pyramidal neurons. After certain forms of injury, mossy fibers that have presumably lost their normal, postsynaptic contacts appear to grow into the stratum granulosum and stratum moleculare, making aberrant contacts with DGC dendrites and basket cells (Frotscher and Zimmer, 1983; Franck et al., 1995). Abnormal growth into the stratum moleculare of CA3 can also be observed. The functional consequences of this injury-induced axonal reorganization are unclear, but it is likely that the altered synaptic connectivity leads to a change in the overall excitability of the DGCs (Cronin et al., 1992; Sloviter, 1992).

The mechanisms underlying the morphological plasticity of DGCs are essentially unknown. Anatomical data support the concept that a mossy fiber elongates and is attracted toward the granular and supragranular layers (Isokawa et al., 1993; Franck et al., 1995). A number of molecules that may be involved in this process have been identified via studies of seizure- and injuryinduced gene expression. In particular, the expression of certain neurotrophins, neurotrophin receptors, and other growth factors can be altered by different forms of neuronal activation (for review, see Eide et al., 1993). For example, mRNAs encoding nerve growth factor (NGF) (Ballarin et al., 1991; Ernfors et al., 
1991; Lautcrborn ct al., 1994), brain-derived neurotrophic factor (BDNF) (Ballarin et al., 1991; Isackson ct al., 1991; DugichDjordjevic et al., 1992a), and the trkB tyrosine kinase receptors are acutely upregulated in DGCs after seizures (Bengzon et al., 1993), and a sustained clcvation of NGF-like and ciliary neurotrophic factor (CNTF)-like activity in protein cxtracts derived from sprouting hippocampi has also been observed (Lowenstein ct al., 1993). A functional role of neurotrophins in these processes is supported by recent studies showing that chronic infusions of anti-NGF antibodics partially block scizure-induccd sprouting in the hippocampus (Van der Zce et al., 1995; Holtzman and Lowenstein, 1995).

These observations, as well as the numerous studies showing that growth factors can modify growth characteristics in different neuronal subtypes in the peripheral and CNS (Fide ct al., 1993), suggest that growth factors are good candidates for the molecular signals that may be directly involved in DGC plasticity. Nonetheless, very litule is known regarding the effects of various growth factors on DGCs. A majority of studics of growth factors and hippocampal neurons have relied on primary cultures derived from whole hippocampi harvested from embryonic day 17 (E17) or E18 animals. During this period, there is a peak in neurogenesis of pyramidal cells and some interneurons, whereas only a minority of the DGCs have appeared (Altman and Bayer, 1990a,b). Cultured cells derived from the late embryonic hippocampus that express neuronal markers are therefore likely to be predominated by a mixed population of pyramidal neurons and interneurons. Based on such culture systems, different neurotrophins and growth factors have becn shown to have a varicty of phenotypic effects on neurons. For example, Ip et al. (1993) found that BDNF, neurotrophin-3 (NT-3), and NT-4 caused phosphorylation of trk receptors and induction of c-fos mRNA and protein in cells from E18 hippocampi, although there were no obvious effects on cell survival. NT-3 has been shown to increase the percentage of hippocampal neurons expressing calbindin-D28K without affecting the overall number of neurons, suggesting that NT-3 influences the neurochemical differentiation of these cells during development (Collazo et al., 1992). Furthermore, bFGF has been shown to enhance the amount of neurite branching in E18 hippocampal cultures (Miyagawa et al., 1993; Aoyagi et al., 1994).

To address the potential effects of neurotrophins and other growth factors on DCiCs more directly, we have carried out a series of experiments in which various growth factors were added to cultures of dentate gyrus ncurons derived from the neonatal rat. Our studies were based on the assumption that insight into the mechanisms of plasticity of adult DGCs may be gained by study of the mechanisms normally operative during development. Application of an ultramicrodissection technique allowed us to prepare cultures that were highly enriched for DGCs, and immunocylochemistry was used to identify probable neurons or neuron precursors. Our results suggest that the growth characteristics of dentate gyrus neurons are significantly influenced by specific growth factors, and that these effects have particular developmental and temporal constraints. We also provide evidence for an endogenous neurotrophin activity in the cultured cells that can be revealed by altering the culture plating densities and using antagonists of specific neurotrophins.

\section{MATERIALS AND METHODS}

Materials. Postnatal day 3 (P3) to P12 Spraguc-Dawley rat pups were obtained from Bantin and Kingman, and all experiments were carried out with approval by the Committec on Animal Research at the University of California, San Francisco (UCSF). The following ragents were kindly provided by fellow investigators at UCSF: NGF (2.5S) from William Moblcy; rccombinant human BDNF from supernatants of transfected Chincse hamster ovary (CHO) cells grown in serum-free medium (originally supplied by Patricia OIsen, Chiron) and purified human BDNF from F. Eide and L. Reichardt; CNTF was from F. Longo, and basic fibroblast growth factor (bFGF; Chiron) was from M. Tessier-Lavigne. NT-3 and NT4/5 were obtained from F. Hefti and A. Rosenthal at Genentech (San Francisco, CA). Initial studics of BDNF used both the CHO supernatant material and purified BDNF-the supernatant was tilered against purificd matcrial to estimate the bioactive BDNF concentration in the nonpurified material. The latter was used in all of the remaining experiments. To check ongoing reliability, most experiments also included tests with the purified material; results were uniformly comparable. Unless otherwise specified, culture medium was comprised of Ncurobasal with $2 \%$ B-27 supplement (Gibco, Grand Island, NY) (Brewer et al., 1993) and $1 \%$ pen/strep (ICSF Cell Culture Facility) Antibodies for immunocytochemistry included neuron-specific enolase (NSE; Dako, Carpeteria, CA), microtubule-associated protein-2 (M^P 2; Sigma, St. Louis, MO), neurofilament-2 (Sigma), vimentin (Dako), and glial fibrillary acidic protein (GFAP; Boehringer Mannheim, Indianapolis, IN). K252b (Calbiochem, San Diego, CA) was reconstituted in dimethylsulfoxide as a $1 \mathrm{~mm}$ stock solution.

Trk-IgG lusion proteins designed to have blocking activity against specific neurotrophins were kindly provided by D. Shelton (Genentech) and were prepared as described in the article by Shelton et al. (1995). In brief, chimeric cDNAs including the extracellular domain of human trkA (the high-alfinity NGF receptor) or LrkB (the high-affinity BDNF receptor) and $\lg G F C$ domains were subcloned into a plasmid expression vector. These were used for transient transfection of 293 cells, and trk-IgC chimerie proteins were purified from the culture media. Competitive displacement studies of the fusion proteins hate shown that they effectively bind neurotrophins specifically and with high affinity (the estimated IC $C_{50}$ for $1 \mathrm{rkA}-\mathrm{Ig}$ ( $)$ wis $62 \mathrm{pM}$ for $\mathrm{NGF}$, and the estirnated $\mathrm{IC}_{50}$ for trkB-Ig(i wals 62 pM for BDNF) (Shelton et al., 1995). The fusion proteins have also been shown to block the biological activity of their respective ligands with high specificity when tested in in vilo bioassalys (Shelton et al., 1995).

Cell culture. Rat pup hippocampi of specified ages were dissected free from surrounding structures using small weighing spatulas and placed on a guillotine tissue chopper. Slices $(500 \mu \mathrm{m})$ were cut transverse to the lnng axis of the hippocampus and placed in a sterile, plastic Petri dish containing Neurobasal/B-27 at $4^{\circ} \mathrm{C}$. The dentate gyrus was dissected free from the hippocampus proper by making an initial cul with sharpened tungsten necdles along the hippocampal fissure that extended laterally beyond the blades of the DGC layer, followed by a second cut, at right angles to the first, which isolated the dentate gyrus. To enrich further for DGCs, a wedge of the dentate hilus was removed by making two angled cuts that met at the vertex of the hilus (Fig. 1). Approximately $20 \mathrm{DGC}$ slices were recovered from two hippocampi. These were collected together in a $15 \mathrm{ml}$ polystyrene centrifuge tube filled with Neurobasal/B-27 and warmed in a $37^{\circ} \mathrm{C}$ water bath for 10 mitn. The tissue was then centrifuged at $200 \times g$ for 3 min, the supernatant was removed, and the tissue was resuspended in $5 \mathrm{ml}$ of $0.8 \%$ trypsin/Ncurobasal/B-27 and incubated at $37^{\circ} \mathrm{C}$ for $15 \mathrm{~min}$. The tissue was centrifuged again at $200 \times$ $g$ for 3 min, and cells were resuspended in Neurobasal/B 27 and triturated gently with a siliconized glass pipette until visibly dispersed (this usually required 25-30 cycles of trituration). Once dispersed, the material wats

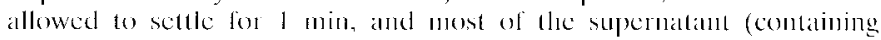
dissociated cells) was transferred to a new $15 \mathrm{ml}$ centrifuge tube. This wals centriluged at $200 \times g$ for 5 min and brielly triturated again to disperso cells, and cell counts were made using a hemocytometer and trypan blue to identify nonintact cells. The cells were then plated at various specified densities onto 96-well plates (Costar, Cambridge, MA) coated with polyL-ornithine $(2 \mu \mathrm{g} / \mathrm{ml}$; Sigma) containing $50 \mu \mathrm{l}$ of Neurobasal/B-27 and additional factors as described. The cultures were incubated at $37^{\circ} \mathrm{C}$ in a $5 \% \mathrm{CO}_{2} / 95 \% \mathrm{O}_{2}$ incubator for $3-12 \mathrm{~d}$.

Inmunocytochemistry. Dissociated cells in 96-well plates were fixed with $4 \%$ paraformaldehyde for $2 \mathrm{hr}$ at room temperature. After washing threc times with $0.1 \mathrm{M}$ Tris buffer, pII 7.6, the cells were treated with $1 \%$ hydrogen peroxide in Tris buffer for $30 \mathrm{~min}$, washed with Tris buffer, Tris A $(0.1 \%$ Triton $\mathrm{X}-100$ in Tris buffer $)$ for 15 min and Tris B $[0.1 \%$ Triton $\mathrm{X}-100,5 \mathrm{mg} / \mathrm{ml}$ bovine serum albumin (BSA) in Tris buffer] for $15 \mathrm{~min}$, blocked with $10 \%$ normal horse serum for 1 hr, washed with Tris A for 15 


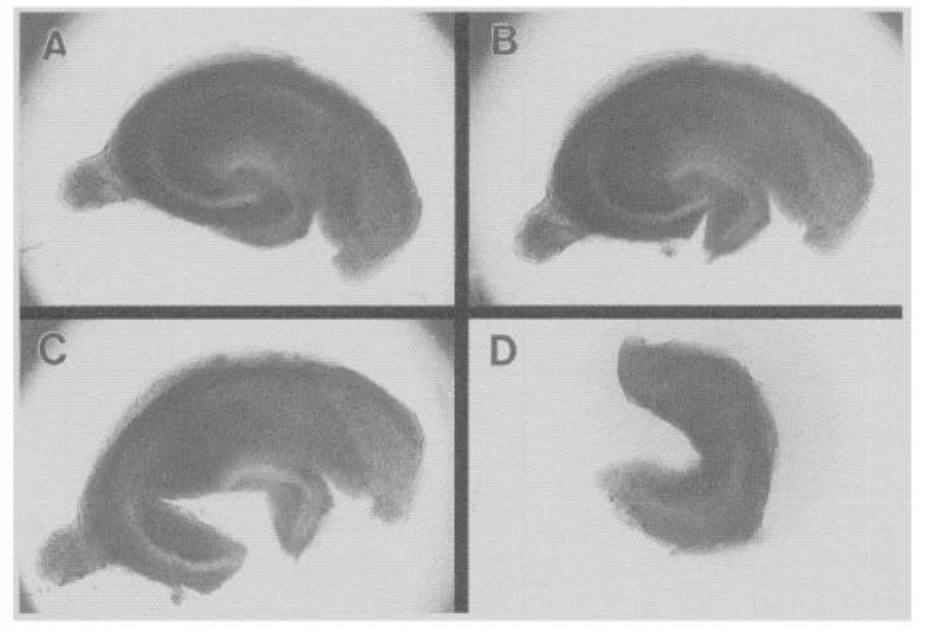

Figure 1. Dissection technique for isolating dentate gyrus neurons. $A, 500$ $\mu \mathrm{m}$ slice from midregion of the hippocampus from a P5 rat. The DGC and pyramidal cell layers are relatively bright when the image field of the dissecting microscope is illuminated from below. $B$, Using one tungsten needle to hold the slice in place and the other to make cuts, we made the initial cut along the lower half of the hilus to isolate the inferior DGC blade from the CA3c pyramidal layer. $C$, A second cut was made at right angles to the first to isolate the superior DGC blade. $D$, This is followed by a cut along the hippocampal fissure to free the DGC layer. Magnifications: $A-C, 10 \times ; D, 13 \times$.

min, Tris B for $15 \mathrm{~min}$, and incubated overnight with primary antibodies (1:200 to $1: 1000$ dilution depending on the specific antibody). The cultures were then rinsed with Tris A and Tris B for 15 min each, exposed to biotinylated horse anti-mouse IgG (rat-absorbed; 1:200 dilution or 5 $\mu \mathrm{l} / \mathrm{ml}$ ) for $45 \mathrm{~min}$, washed with Tris A and Tris B for $15 \mathrm{~min}$ each, and incubated in avidin-biotin complex (Vectastain Elite, Vector Laboratories, Burlingame, CA) diluted 1:1000 in Tris buffer for $1 \mathrm{hr}$. The cells were then washed three times for $5 \mathrm{~min}$ with Tris buffer and stained with a reaction mixture comprised of $10 \mathrm{mg}$ of $3,3^{\prime}$-diaminobenzidinetetrahydrochloride, $20 \mu \mathrm{l} \mathrm{of} 3 \mathrm{mg} / \mathrm{ml}$ glucose oxidase, $40 \mu \mathrm{l}$ of $200 \mathrm{mg} / \mathrm{ml}$ ammonium chloride, and $160 \mu \mathrm{l}$ of $250 \mathrm{mg} / \mathrm{ml} \mathrm{D}$-glucose in $20 \mathrm{ml}$ of Tris buffer. This was made immediately before use and was allowed to react for $10 \mathrm{~min}$ at room temperature before being added to cultures.

For fluorescence immunocytochemistry, dissociated cells were plated on 8-well glass chamber slides (Nunc, Naperville, IL). Cultured cells were rinsed for $5 \mathrm{~min}$ with Tris-buffered saline (TBS; $10 \mathrm{~mm}$ Tris, $\mathrm{pH}$ 7.0, 150 $\mathrm{mm} \mathrm{NaCl})$. They were incubated in TBS blocking buffer (1\% glycine, $0.4 \%$ Triton X-100, 3\% BSA, and $10 \%$ normal goat serum in TBS) for 1-2 hr, and incubated overnight at room temperature with primary antibodies (1:200 to 1:1000 dilution depending on the specific antibody) diluted in TBS blocking buffer. Cells were then rinsed in TBS five times for $20 \mathrm{~min}$ each, exposed to TBS blocking buffer for $1 \mathrm{hr}$, and then incubated with fluorescein isothiocyanate-conjugated goat anti-mouse antibody (1:200 in TBS blocking buffer) for $1 \mathrm{hr}$. Cells were rinsed again in TBS five times for $20 \mathrm{~min}$ each, coverslipped using glycerol-based mounting medium (Sigma), and visualized with fluorescence microscopy.

Data analysis. Neurons were selected for quantitative analysis by positioning the field of view $(200 \times$ magnification) in a random spot within each well and moving down until 10 neurons were measured. Only those cells staining positive for NSE were included. The processes were measured from cell body to tip or, if branched, from the cell body to the longest tip, and the average process lengths were recorded. Thirty to sixty neurons per condition per trial were measured. Measurements of process lengths were made using an ocular micrometer. Measurements were analyzed in $U$, where $1 \mathrm{U}=5 \mu \mathrm{m}$. Cell counts were measured by counting all NSE-positive cells in each well.

Statistics. Statistics were calculated using StatView (Abacus, Calabasas, CA) for the Macintosh. Factorial ANOVA was used to compare the effects of various treatment conditions on average process length or cell counts, and Scheffe's post hoc test was applied for individual comparisons if the ANOVA was significant with $p<0.05$.
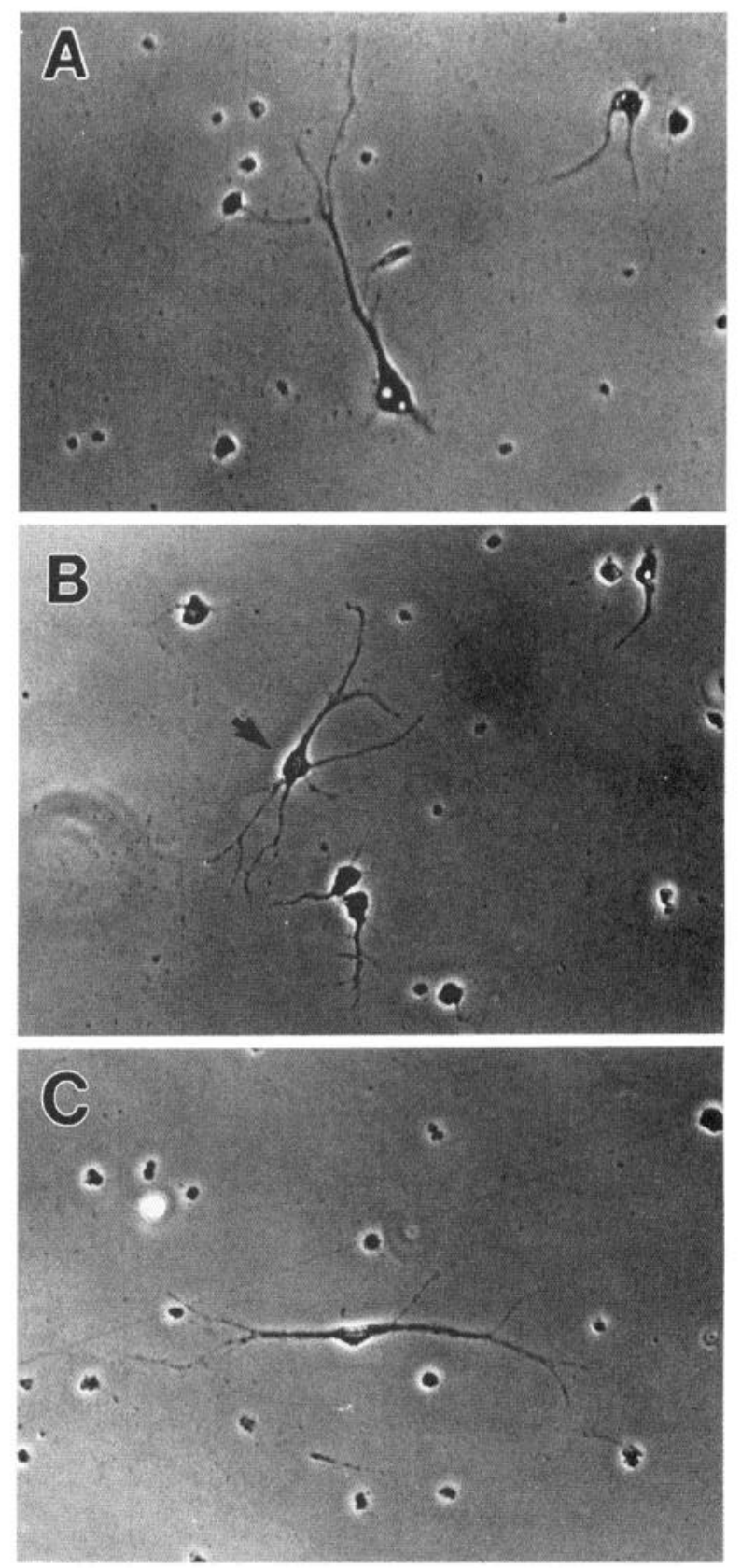

Figure 2. Morphology of NSE-positive neurons in cultures of dentate gyrus neurons. $A$, Putative DGCs are characterized by round to ovoid cell bodies and branching processes that extended asymmetrically from the cell soma. Putative interneurons include NSE-positive cells with multiple, branching processes having some similarity to hilar mossy cells $(B)$, and bipolar cells similar to somatostatin-positive hilar interneurons $(C)$. Magnification: $340 \times$.

\section{RESULTS}

\section{Morphological and immunohistochemical characteristics of dentate gyrus cultures}

Within $48 \mathrm{hr}$ of plating, the dentate gyrus cultures began to show heterogeneity in the morphology of different cells. Some cells had obvious characteristics of neurons and, based on their size and shape alone, appeared to be DGCs. These putative granule cells had relatively small, oval cell bodies with a long diameter of $\sim 15$ $\mu \mathrm{m}$, and bipolar, thin neuritic processes that were asymmetric in length and had growth cones at the endings of some processes. 

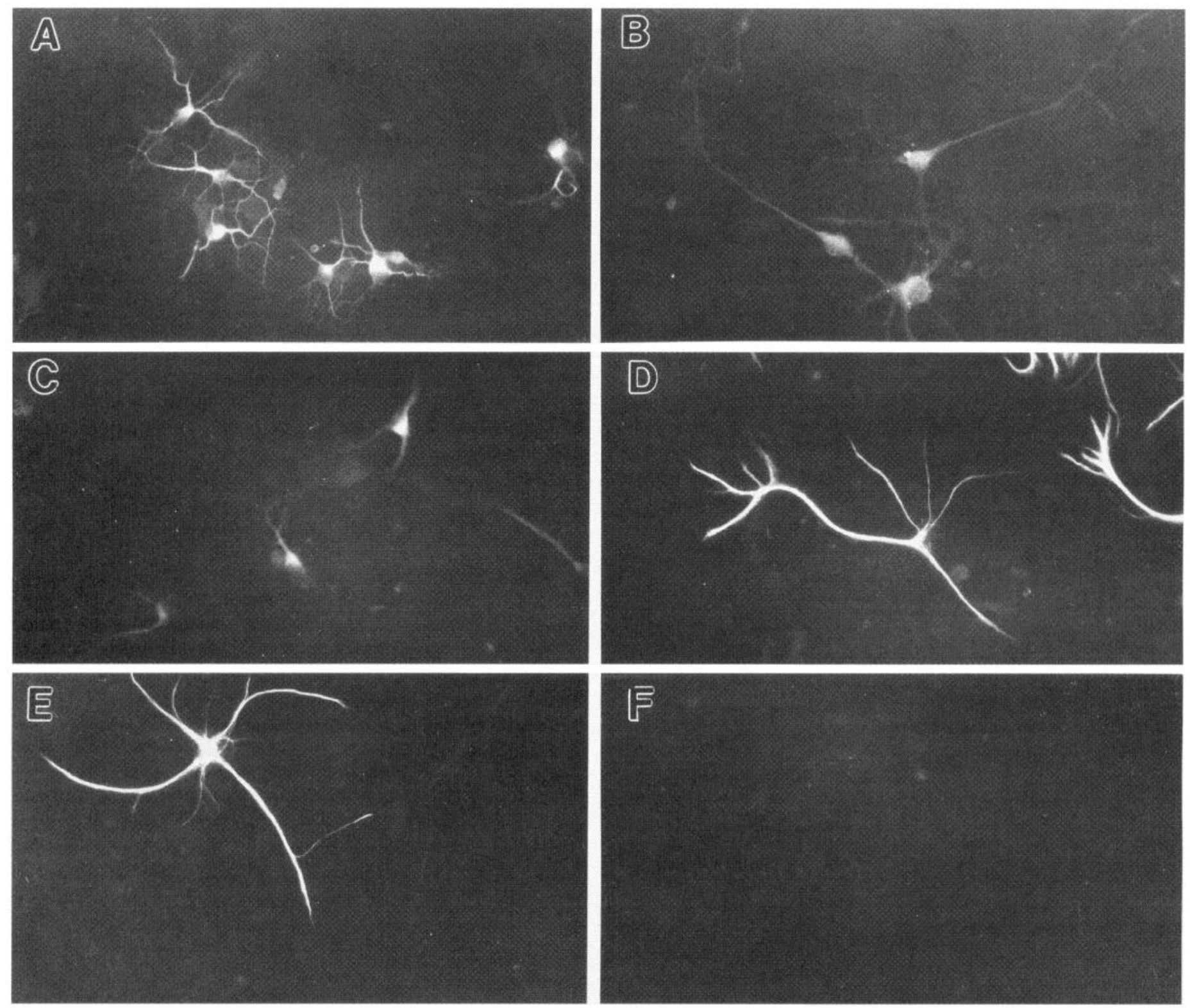

Figure 3. Immunocytochemical staining of cultures of dentate gyrus neurons. $A$, MAP-2 immunoreactivity shows staining primarily in cell soma and multiple, thin processes that have profiles consistent with dendrites. $B$, Neurofilament- 2 immunoreactivity was confined to cell soma and longer, branching processes suggestive of axons. $C$, Dynorphin immunoreactivity was observed in a subset of cells, although it was typically faint. Cells having glial morphology were staining by either anti-vimentin $(D)$ or anti-GFAP $(E)$. $F$, No staining of cells was seen when the cultures were incubated with the secondary antibody alone. Magnification: $188 \times$.

The other morphologically distinct cells had long, elliptiform cell bodies and relatively thick processes with angular endings, and were presumably glial cells. Other cells were more difficult to classify based on morphology alone, because they appeared to be less differentiated, or had neuronal characteristics but were not obviously DGCs in terms of cell body size and pattern of neurite growth. After $2 \mathrm{~d}$ in culture, there was typically a progressive decrease in the number of cells in the culture plates, and numerous cells had clearer characteristics of neurons; i.e., many of them had multiple, thin, branching processes suggestive of dendrites or axons. By $12 \mathrm{~d}$ in culture, an increase in the proportion of pleiomorphic cells with glial morphology became evident.

Immunocytochemical staining with a variety of neuronal and glial markers demonstrated that the cultures contained mixed populations of cells, consistent with the differences in morphology described above. Cells with positive staining for NSE included two distinct cell types (Figs. 2, 3). The first were the putative DGCs described above. The second were possible dentate gyrus interneurons that had either multiple neuritic, branching processes reminiscent of the hilar mossy cell, or bipolar cells similar to the somatostatin-positive hilar interneurons observed in the mature dentate hilus. MAP-2 immunoreactivity in neuronal cells was observed on multiple thin, branching processes that frequently arose asymmetrically from the cell body and appeared to have a dendritic morphology (Fig. 3). Neurofilament-2 staining was also seen in neuronal cells, but was confined to a few, longer processes suggestive of axons. Immunoreactivity of cells with an antidynorphin antibody was either faint or absent, similar to observations made previously by others (Boss et al., 1987). Intense staining with anti-vimentin and anti-GFAP antibodies was seen in a 

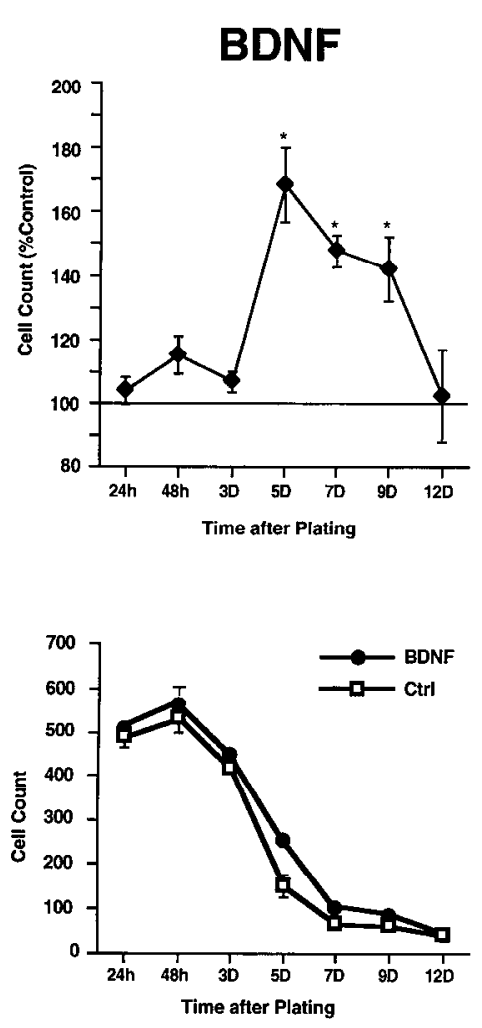
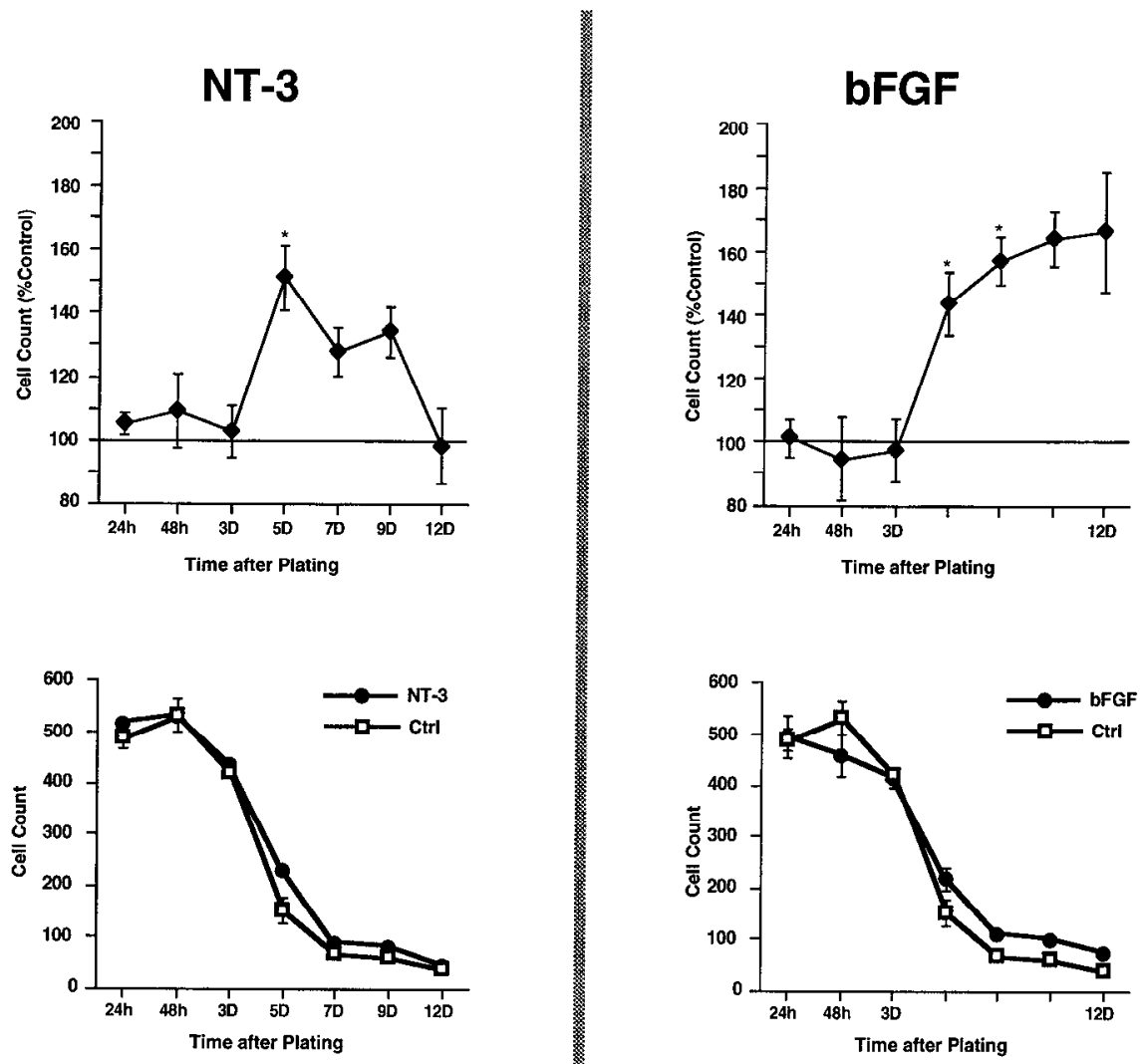

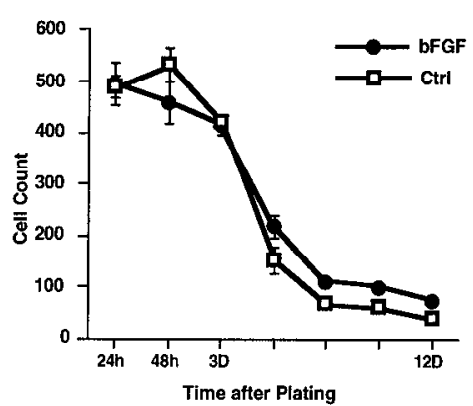

Figure 4. The effects of BDNF, NT-3, and bFGF on the relative and absolute survival of NSE-positive dentate gyrus neurons over time. The top graph in each of the three panels shows the relative number of neurons/well surviving compared with control conditions measured at different time intervals after initial plating of P5 cells at densities of $2 \times 10^{4}$ cells/well. The bottom graphs show the absolute cell counts. Values are shown as mean $\pm \mathrm{SE}$ based on a sample of at least four to eight wells in at least two separate experiments. ANOVA revealed significant differences between control and growth factor-treated cells in all three cases; significant differences at specific time points by the Scheffe's post hoc test are indicated by asterisks. Note the gradual but consistent decline in total NSE-positive cells over time in all conditions, with relative survival of cells treated with $B D N F, N T-3$, or $b F G F$.

minority of cells having the appearance of glia (Fig. 3). Some staining with glial markers was also observed in cells that were less clearly differentiated and may represent neuronal or glial precursors.

\section{Effects of growth factors on dentate gyrus neurons over time}

In an initial set of experiments, various growth factors were tested on dentate gyrus cultures harvested at P5 and grown for 1, 2, 3, 5, 7,9 , or 12 days. As shown in Figure 4, all cultures had a progressive decline in the number of surviving NSF-positive cells per well over a time. At a plating density of $1-2 \times 10^{4}$, initial cell counts were $\sim 500 /$ well; this typically declined by a factor of 10 by the end of the experiment at $12 \mathrm{~d}$. Treatment of cultures with BDNF or bFGF caused a significant increase in the relative number of NSE-immunoreactive neurons in each culture well compared with controls (Fig. 4). With BDNF the increase was significant at 5, 7, and $9 \mathrm{~d}$ but returned to control levels at $12 \mathrm{~d}$. A similar pattern was seen with NT-3, with a significant increase only at $5 \mathrm{~d}$. In contrast to BDNF and NT-3, bFGF caused an increase in the number of NSE-positive cells that was significant at $5 \mathrm{~d}$ and remained so for the duration of the experiment. In addition to this effect on cell number, both BDNF and bFGF caused a sustained increase in the average process length of NSE-immunoreactive cells, and this was most notablc aftcr 5-7 d in culture (Fig. 5). NT-3 also caused an increase in average process length, although the only individual time point with a significant increase in average process length over control conditions was $12 \mathrm{~d}$. None of the other growth factors tested (NGF, NT-4/5, and CNTF) had significant effects on average process length or the number of NSEpositive cells (data not shown).

Because BDNF and bFGF had the most substantial effects on dentate gyrus neurons in the time course experiments, the remainder of our studies focused primarily on these two growth factors. As shown in Figure 6, a dose-response analysis of BDNF and bFGF established that the concentrations chosen a priori for the time course studies (based on previous observations of BDNF and bFGF in other culture systems) were in the range having maximal effects on average process lengths of the dentate gyrus neurons. The remaining experiments were done using a concentration of 50 $\mathrm{ng} / \mathrm{ml}$ for BDNF and $25 \mathrm{ng} / \mathrm{ml}$ for $\mathrm{bFGF}$.

\section{Effects of BDNF, bFGF, and NT-3 on dentate gyrus} neurons harvested at different developmental ages

To determine whether growth factor responsiveness of dentate gyrus neurons was influenced by the developmental age at which the cells were first plated, we examined the effects of BDNF and bFGF on cultures prepared from P3, P6, P9, or P12 animals and grown for $5 \mathrm{~d}$. As shown in Figure 7, BDNF caused a signiticant increase in average process length of NSE-positive cells at all ages tcsted, although the effect was slightly diminishcd in $\mathrm{P} 12$ cultures. bFGF had a significant effect only on P3 and P6 cultures. 

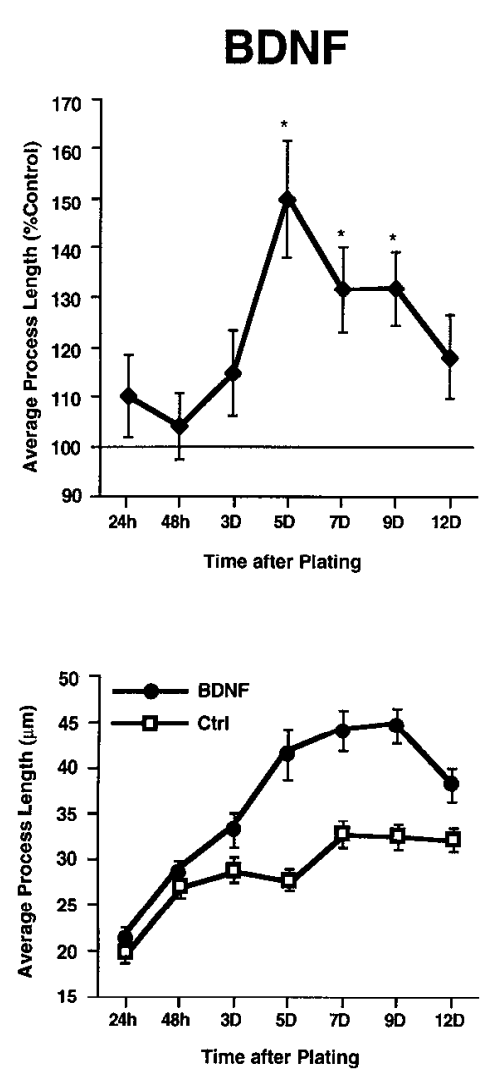
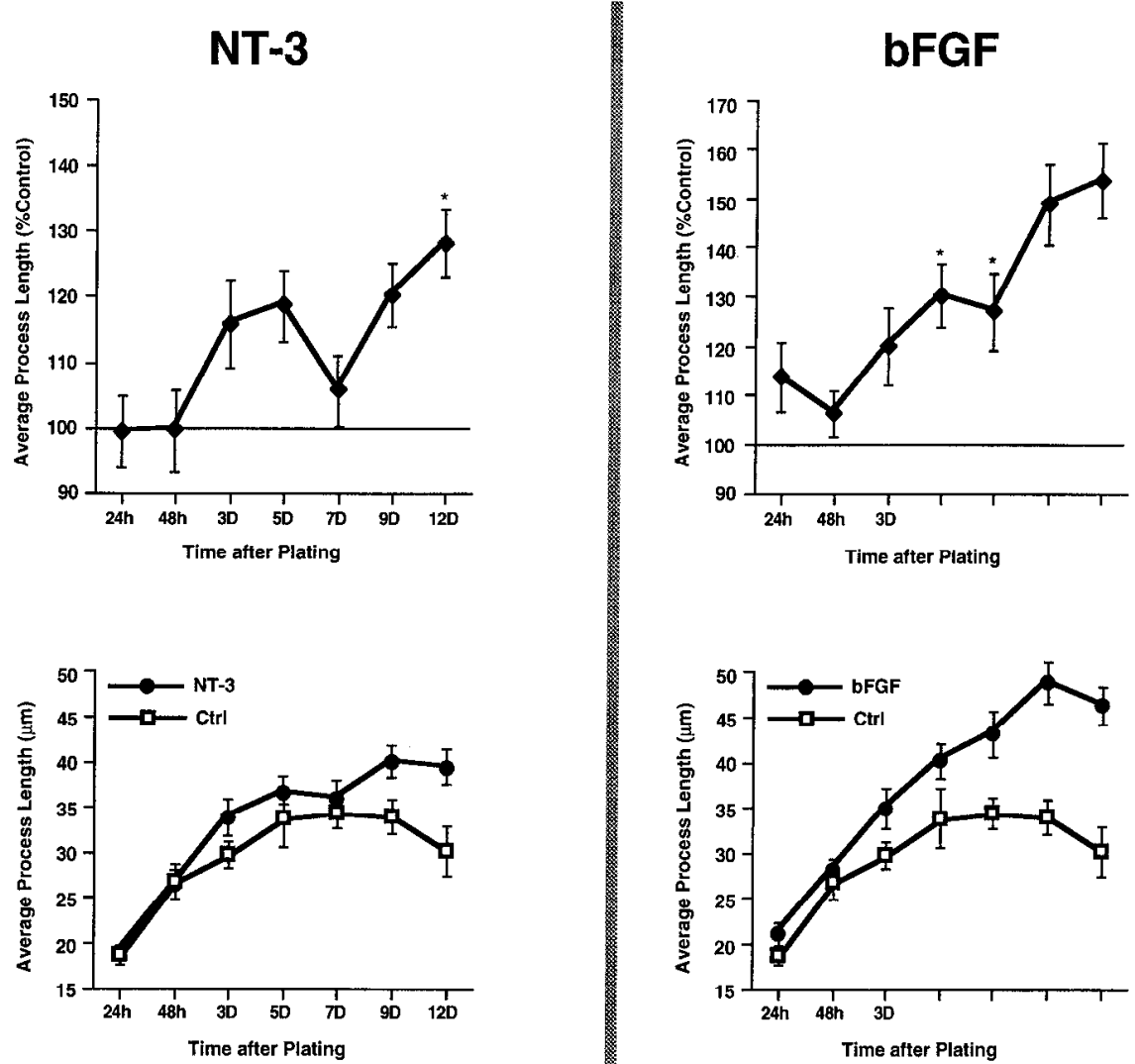

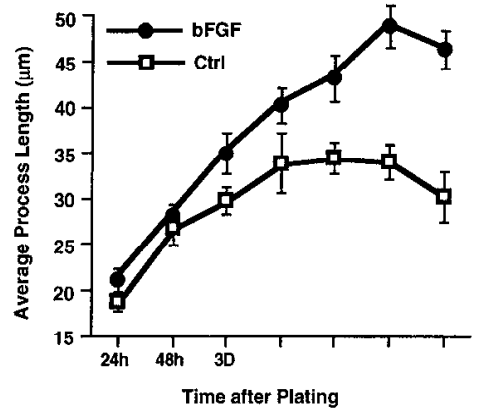

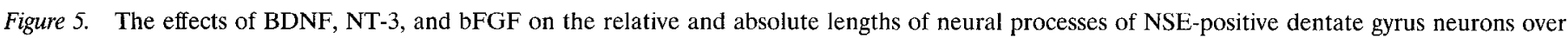

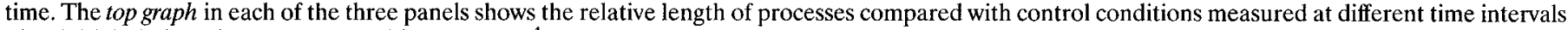

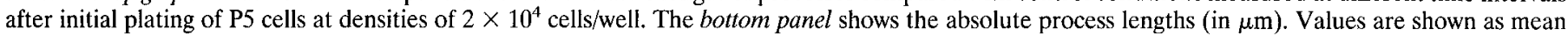

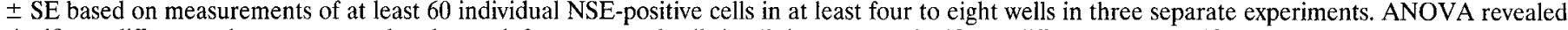

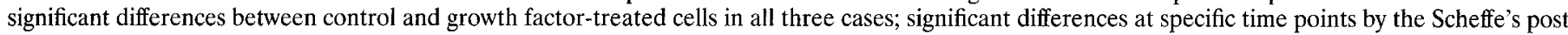

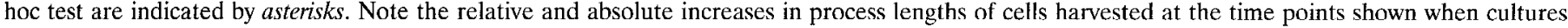
were treated with $B D N F, N T-3$, or $b F G F$.

\section{Evidence for endogenous BDNF-like bioactivity in dentate gyrus cultures}

In pilot studies, we noted that dentate cultures plated at relatively high densities (i.e., $\leq 1 \times 10^{5}$ cells $/ \mathrm{ml}$ ) had similar growth characteristics with and without the addition of growth factors. This suggested that high-density cultures had an endogenous trophic support. To test this, we first compared the effects of BDNF and bFGF on cultures plated over a range of culture densities. As shown in Figure 8, the application of either exogenous BDNF or bFGF had relatively greater effects on neuronal process growth as the cells were plated at lower densities.

To determine whether high-density cultures were producing endogenous, functional trophic factors, we carried out a series of experiments using trk-IgG fusion proteins that have been demonstrated recently to have blocking activity against specific neurotrophins (Shelton et al., 1995). As noted in Materials and Methods, this blocking activity has been shown to be specific for certain neurotrophins. Using low-density cultures, we found that the trkB-IgG fusion protein completely blocked the previously observed effects of BDNF on dentate gyrus neurons (Fig. 9A). When tested with cultures plated at higher densities (i.e., not requiring exogenous growth factors), the trkB-IgG fusion protein significantly reduced the average length of dentate gyrus neuronal processes in a dose-dependent manner, whereas a trkA-IgG con- struct had no effect (Fig. 9B). Furthermore, there was no effect of the trkB-IgG or trkA-IgG fusion proteins on the bFGF-induced changes in growth characteristics of the dentate gyrus neurons (data not shown). These observations suggest that the dentate gyrus cultures produce a biologically active BDNF-like substance.

\section{Evidence that the effects of BDNF on dentate gyrus neurons are mediated through trk receptors}

The evidence that BDNF was having a direct effect on the growth characteristics of the DGCs led us to ask whether this effect was mediated by activation of trkB, the high-affinity BDNF receptor (Glass et al., 1991; Klein et al., 1991; Soppet et al., 1991; Squinto et al., 1991). To explore this, we used the kinase inhibitor $\mathrm{K} 252 \mathrm{~b}$, which inhibits the tyrosine kinase activity of the various trk receptors. Although not specific for trkB, at micromolar concentrations $\mathrm{K} 252 \mathrm{~b}$ is known to suppress BDNF-induced trkB phosphorylation, an essential step in the signal transduction cascade leading to the trophic actions of BDNF and other neurotrophins (Kase et al., 1987). As shown in Figure 10A, addition of increasing concentrations of $\mathrm{K} 252 \mathrm{~b}(1.2-5.0 \mu \mathrm{M})$ progressively attenuated the activity of exogenous BDNF in the dentate gyrus cultures when they were plated at low density. This effect was specific to BDNF in that even the highest concentration of K252b, which completely sup- 

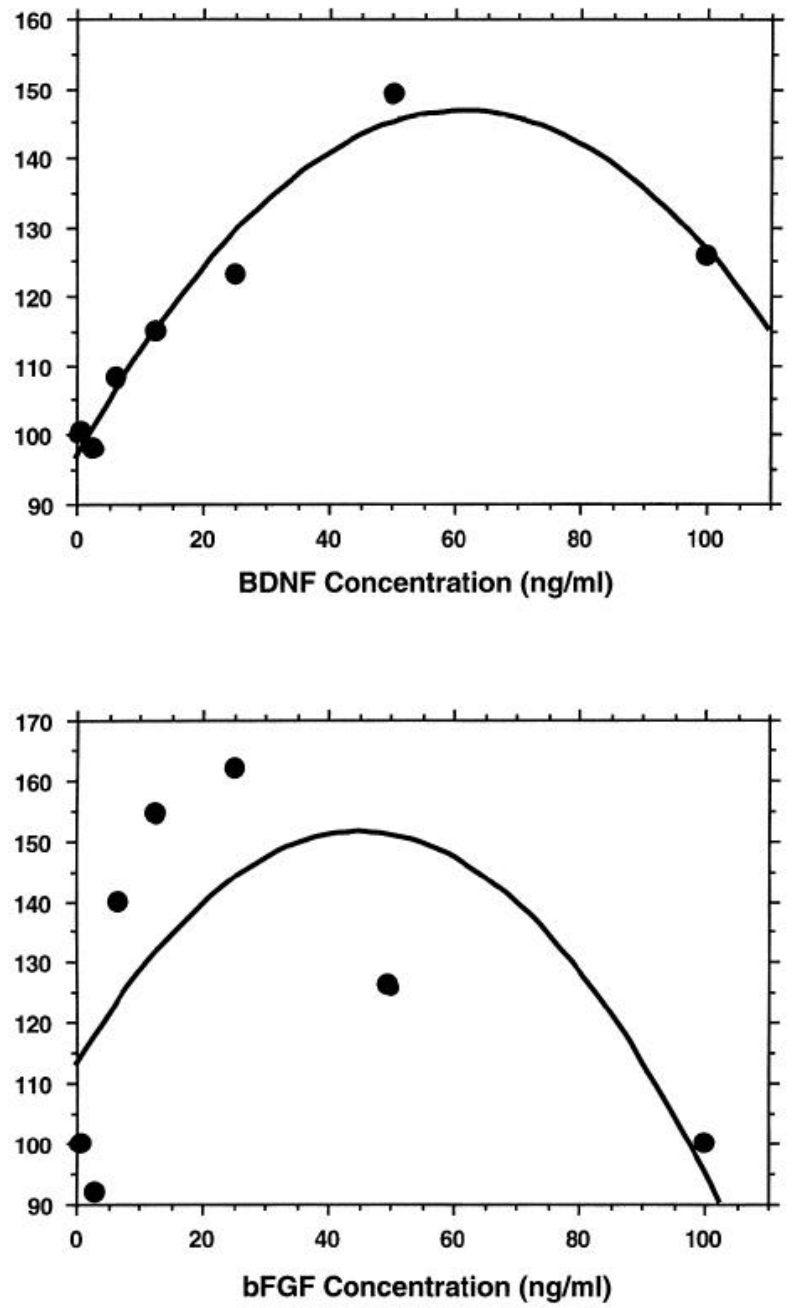

Figure 6. Dose-response of $B D N F$ or $b F G F$ and relative length of neuronal processes in dentate gyrus neurons prepared from P5 neonates and assayed after $5 \mathrm{~d}$ in culture. Average values are based on measurements of at least 40 individual NSE-positive cells in at least four to eight wells in six separate experiments.

pressed BDNF bioactivity, did not influence the effects of bFGF on the cultures.

The effect of K252b on growth characteristics of high-density cultures was evaluated to determine whether the endogenous expression of a BDNF-like substance in cultures plated at relatively high densities was mediated by tyrosine kinase receptors. As shown in Figure $10 \mathrm{~B}, \mathrm{~K} 252 \mathrm{~b}$ attenuated in a dose-dependent manner the average process length of dentate gyrus neurons plated at $1 \times 10^{5}$ cells $/ \mathrm{ml}$. These results support the hypothesis that the actions of an endogenous BDNF-like substance on dentate gyrus neurons are mediated through phosphorylation of the trkB tyrosine kinase receptor.

\section{DISCUSSION}

Previous work has documented the regional localization and developmental expression of growth factors and their receptors in the dentate gyrus. Furthermore, many studies have shown that this expression can be modulated in the dentate gyrus of adult animals by physiological activity such as electrical stimulation. This has led to speculation that activity-induced changes in neurotrophin expression are a critical element in synaptic plasticity

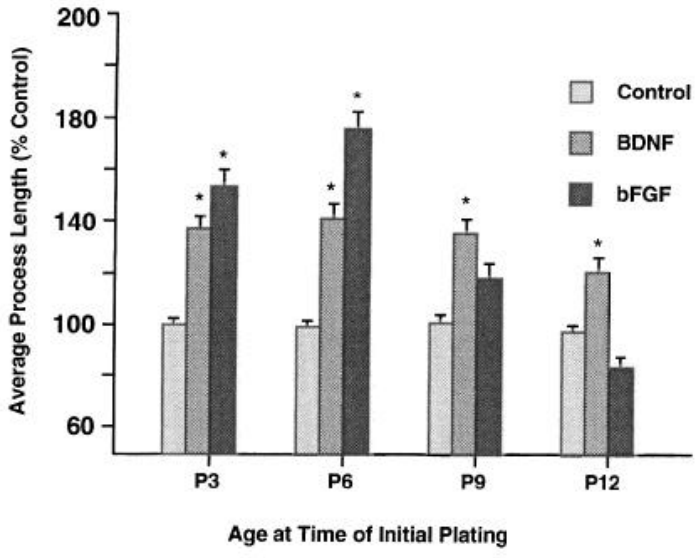

Figure 7. Effects of initial age of dentate gyrus neurons on their responsiveness (i.e., growth of processes) to BDNF or bFGF. Dentate gyrus dissections were carried out at the postnatal days shown, and cultures were maintained in the presence of $B D N F(50 \mathrm{ng} / \mathrm{ml})$ or $b F G F(25 \mathrm{ng} / \mathrm{ml})$ for 5 d. Data are shown in the same format as described in Figure 5. Note that the effects of BDNF were observed for all ages studied, with a peak response at $P 6$, whereas bFGF effects were significant only in $P 3$ and $P 6$ cultures.

and network remodeling. Nonetheless, despite our knowledge of the presence and modulation of growth factor expression within the dentate gyrus, very little is known about the function of these various components either during development or in the mature CNS. The main purpose of this study was therefore to characterize the biological effects of a number of neurotrophins and growth factors on dentate gyrus neurons. Using primary cultures derived from neonatal rats, our results show the following: (1) BDNF and bFGF, and to a lesser extent NT-3, influence the growth and differentiation of dentate gyrus neurons; (2) these effects are time-, concentration-, and age-dependent; and (3) the cultures produce a biologically active BDNF-like substance that appears to act via tyrosine kinase receptors. These findings therefore provide strong evidence that certain growth factors expressed locally within the dentate gyrus are capable of influencing the developmental characteristics of neurons growing within this region.

Primary cultures provide a very useful in vitro system for studying factors that may influence the growth and plasticity of neurons. However, in contrast to the extensive literature on hippocampal cultures, there have been relatively few studies of the factors affecting growth characteristics of neurons derived specifically from the dentate gyrus. Although the preparation of the cultures requires the extra step of microdissection, we found that with practice the isolation of the DGC layer away from the pyramidal cell layer and much of the hilus could be done quickly and with a high degree of precision. Thus, by direct visualization, it was possible to be certain that the great majority of neurons within the tissue used as starting material for the cultures was from the DGC layer. A bias toward selected growth of non-DGCs such as hilar interneurons in these cultures cannot be excluded, and NSE-positive cells of various shapes and sizes were seen (Fig. 2). However, the presence of many NSE-positive cells having the gross morphological characteristics of dentate gyrus neurons suggests that there was some enrichment for these particular neurons using the dissection and plating techniques. In all experiments, there was a gradual and consistent decline in the total number of NSE-positive cells over time. Boss et al. (1987) have shown previously that dentate gyrus neurons can be effectively cultured at low density and over extended periods. The characteristics of 


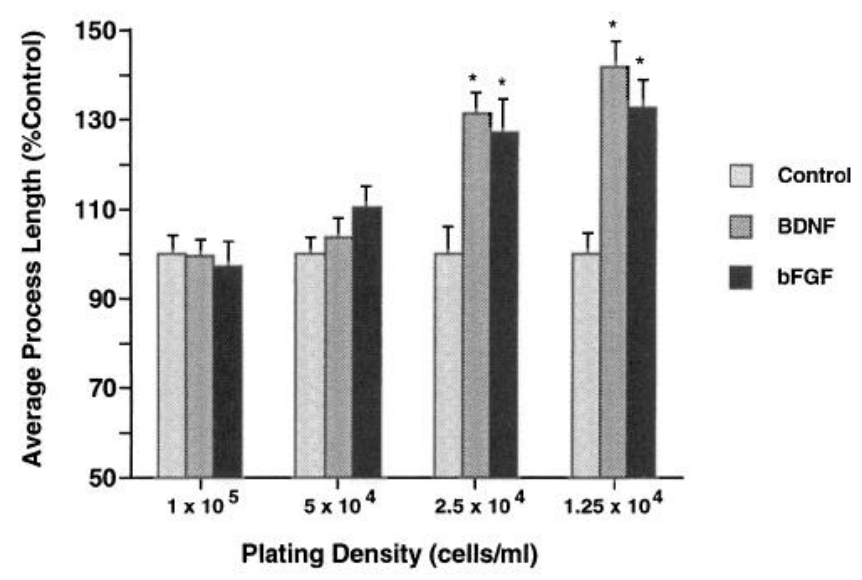

Figure 8. Effects of DGC plating densities on neuronal responsiveness (i.e., growth of processes) to BDNF or bFGF. All experiments used dentate gyrus neurons derived from P5 or P6 neonates and assayed at $5 \mathrm{~d}$. Data are shown in the same format as described in Figure 5. Note that the $B D N F$ and $b F G F$ effects were significant only at relatively lower plating densities.

their culture system differed from ours in a number of ways, including their use of relatively higher plating densities $\left(5 \times 10^{5}\right.$ cells $/ \mathrm{ml}$ ) and the presence of substantially more cells expressing glial markers. The relatively lower ratio of glia to neurons may explain the lack of long-term survival of a large number of neurons in our culture system, because glial support has been shown to be effective in many chronic in vitro preparations (Banker and Goslin, 1991). Nonetheless, both systems point to the feasibility of studying isolated dentate gyrus neurons. This approach has been used recently to show that glucocorticoids have trophic effects on DGCs (Nishi et al., 1994), consistent with some in vivo observations (Sloviter et al., 1989; Gould et al., 1990).

Previous observations that growth factors and their receptors are expressed in the developing dentate gyrus suggest that BDNF and bFGF may affect the growth properties of dentate gyrus neurons. For example, BDNF mRNA expression in DGC bodies is evident as early as P8 and continues to increase into adulthood (Dugich-Djordjevic et al., 1992b). There is also obvious expression of the catalytic form of trkB mRNA in the DGC layer by P4, and this reaches a peak between P13 and P17 (Dugich-Djordjevic et al., 1993). Phosphorylation of trkB in hippocampal tissue induced by BDNF and NT-3 has been shown to peak at P7 (Knusel et al., 1994). Although the cellular location of this interaction remains unknown, these data provide strong evidence for a functional interaction between BDNF and trkB during hippocampal development.

In contrast to the patterns of BDNF and trkB expression, bFGF immunoreactivity is seen in DGCs very early in their development (P1) in the rat. Beyond P4-P6, bFGF expression within the dentate gyrus appears to be restricted to astrocytes (Eckenstein et al., 1994; Gomez-Pinilla et al., 1994). Interestingly, bFGF receptor sites in the dentate gyrus, as measured by ${ }^{125}$ I-binding studies, become evident at least as early as P15 and they are localized specifically along the distribution of DGC axons (Fayein et al., 1992). In situ hybridization studies suggest that mRNA for the FGFR-1, but not FGFR-2 or FGFR-3, is expressed in the DGC layer in the adult (Yazaki et al., 1994). It has also been shown that bFGF expression increases in astrocytes and the extracellular matrix in the molecular layer of the dentate gyrus after an entorhinal cortex or fimbria-fornix lesion in the adult (Gomez-Pinilla
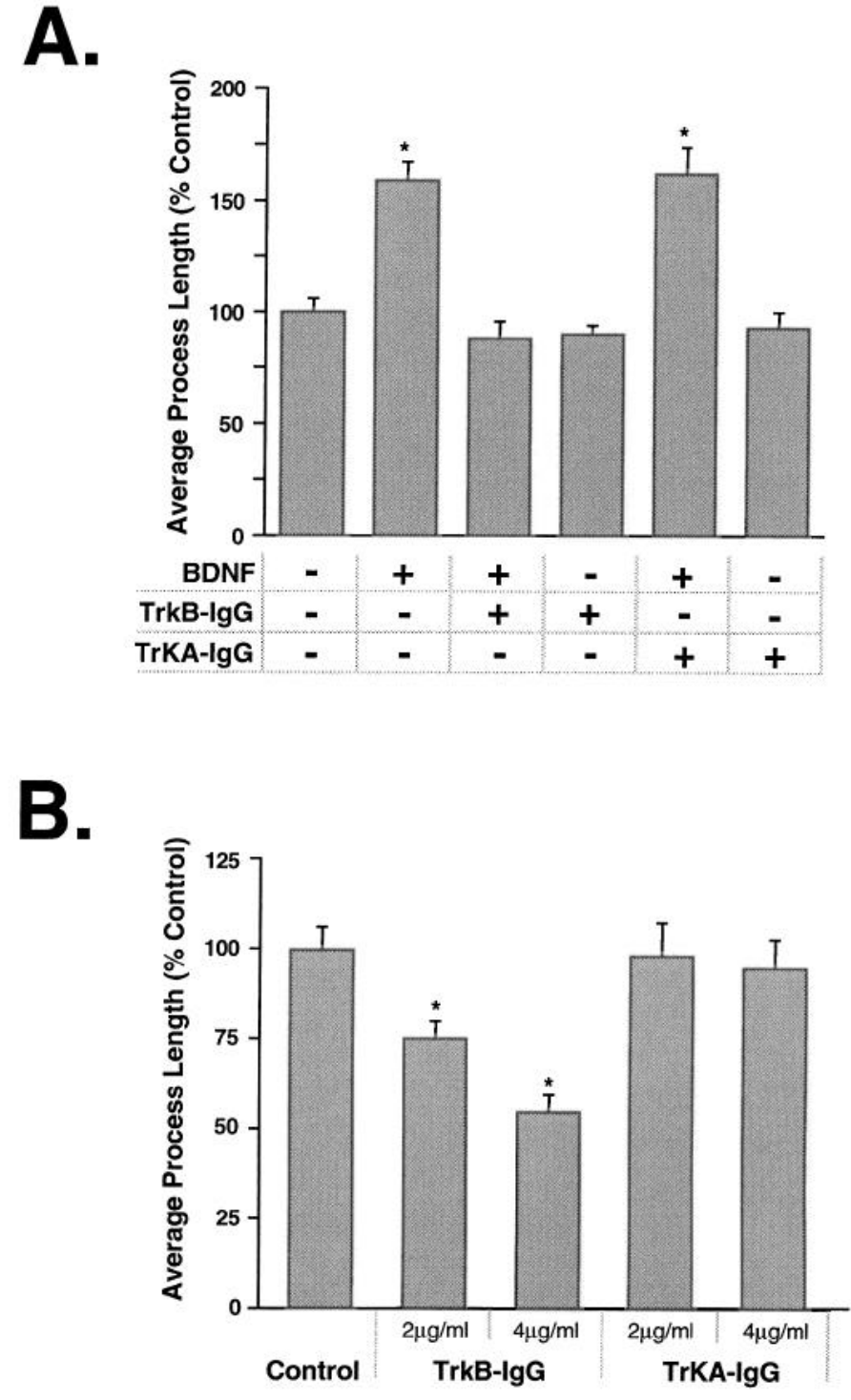

Figure 9. The effects of trk-IgG fusion proteins on growth characteristics of dentate gyrus neurons grown at relatively low $(A)$ and high $(B)$ plating densities. $A$, The effects of $B D N F(50 \mathrm{ng} / \mathrm{ml})$ on average process length of neurons plated at low density $\left(2 \times 10^{4} \mathrm{cells} / \mathrm{ml}\right)$ was completely blocked when cultures were grown in the presence of the $\operatorname{trkB}-\lg G$ fusion protein $(4 \mu \mathrm{g} / \mathrm{ml})$ but not the $t r k A-I g G$ fusion protein $(4 \mu \mathrm{g} / \mathrm{ml})$. Note that neither fusion protein significantly changed average process lengths of control cultures grown without added BDNF. $B$, When added to cultures plated at higher densities $\left(1 \times 10^{5}\right.$ cells $\left./ \mathrm{ml}\right)$, the $\operatorname{trkB}-\operatorname{Ig} G$ fusion protein (but not the $\operatorname{trk} A-\operatorname{Ig} G$ fusion protein) significantly attenuated average process lengths of neurons in a dose-dependent manner. All cultures were derived from P5 or P6 neonates and assayed at $5 \mathrm{~d}$. Data are shown in the same format as described in Figure 5.

et al., 1992). These various observations have led to the suggestion that bFGF exerts trophic effects on neurons in the dentate gyrus during development and after injury, an idea that has received support from both in vitro (Mattson et al., 1989, 1993; Louis et al., 1993) and in vivo studies (Anderson et al., 1988).

Our observations extend this previous work by providing the first direct evidence for the responsiveness of DGCs to BDNF and bFGF. The maximal effect of BDNF was seen $\sim 5 \mathrm{~d}$ after plating in cells derived from $\mathrm{P} 3-\mathrm{P} 9$ animals (i.e., cultured cell ages of P8-P14). This time course, therefore, is reasonably within the temporal pattern of BDNF responsiveness based on in vivo ob- 
A.

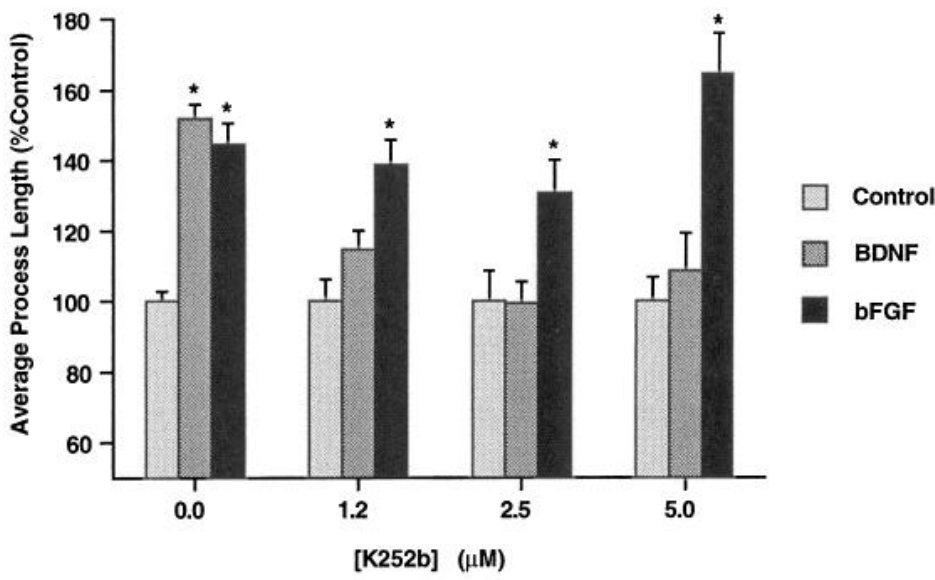

B.

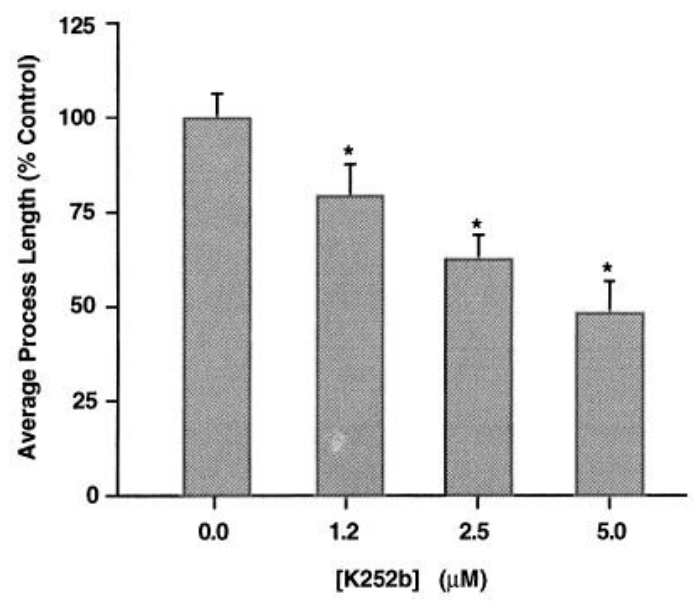

servations. Interestingly, the relative increase in neuron survival peaked at $5 \mathrm{~d}$ after plating of cells and returned to control values at $12 \mathrm{~d}$, whereas the effect on average process length became significant at $5 \mathrm{~d}$ and remained elevated through to $12 \mathrm{~d}$. The basis for this temporal uncoupling of the effects of BDNF on cell survival versus differentiation (as measured by average process length) is unclear. Different mechanisms may contribute to these various trophic changes, although selective survival of more differentiated cells is a possible explanation for these observations. In contrast to BDNF, bFGF led to an ongoing significant increase in both relative neuronal survival and differentiation from 5 to 12 $\mathrm{d}$. This time course may be explained, in part, by the relatively late appearance of FGF receptors in the dentate gyrus (i.e., P15 with increased expression by P30) (Fayein et al., 1992). Again, because the overall number of neurons declined over time, it is possible that the effects of bFGF are attributable to selective survival or differentiation of a subset of cells.

In addition to finding that exogenous BDNF influenced the growth of the cells, a number of observations support the conclusion that cells derived from the microdissected dentate gyrus produce endogenous BDNF. There was a clear effect of plating density of the cells, such that at relatively higher densities there was no added benefit of adding BDNF (or bFGF) to the culture. Furthermore, the trk-IgG fusion protein significantly reduced the average process length of neurons plated at high density by as much as $50 \%$ in a dose-dependent manner. Because the trkB-IgG fusion protein is capable of binding either BDNF or NT4/5, we cannot exclude the possibility that the endogenous factor was NT4/5. However, this seems unlikely because the low-density cultures were substantially more responsive to BDNF than to NT4/5. It is also notable that the cultures were not affected by treatment with the trkA-IgG protein, suggesting that endogenous NGF was not influencing the growth parameters studied.

There are a number of important caveats that must be recognized in the interpretation of these results. First, although an in vitro tissue culture system provides a very useful means for mechanistic studies, it likely represents a major perturbation of the normal in vivo environment. This may be especially true in microdissected culture systems that are relatively selective for neurons. Thus, the responsiveness of the cultured cells to BDNF or bFGF may not reflect the processes operative during development. Second, despite the microdissection technique, the NSE-positive cells were somewhat heterogeneous and included "polymorphic" cells that were likely to be dentate gyrus interneurons. We therefore chose to refer to the cultured cells as dentate gyrus neurons rather than DGCs. Third, the presence of non-NSE cells in the cultures emphasizes the possibility that many or all of these findings may be critically mediated by glia or other non-neuronal cells. Finally, because of the many conditions and reagents studied, we limited the main end-points of our experiments to measurements of cell 
counts and average process length. It is possible that other characteristics of differentiation, such as axonal branch points, polarity, etc., could be influenced by the growth factors used in these studies.

In summary, our findings demonstrate that BDNF and bFGF exert significant trophic effects on neurons derived from the neonatal rat dentate gyrus. This is consistent with previous observations in vivo showing that cells from this region normally express these factors and their receptors during development. Furthermore, these studies provide the first direct evidence for the production by DGCs of a biologically active BDNF-like substance that acts via a tyrosine kinase receptor. This advances the hypothesis that BDNF plays an important role in the normal differentiation of DGCs during development. The involvement of BDNF or its receptor in DGC plasticity in the mature CNS remains to be determined.

\section{REFERENCES}

Altman J, Bayer S (1990a) Migration and distribution of two populations of hippocampal granule cell precursors during the perinatal and postnatal periods. J Comp Neurol 301:365-381.

Altman J, Bayer S (1990b) Mosaic organization of the hippocampal neuroepithelium and the multiple germinal sources of dentate granule cells. J Comp Neurol 301:325-342.

Anderson K, Dam D, Lee S, Cotman C (1988) Basic fibroblast growth factor prevents death of lesioned cholinergic neurons in vivo. Nature $332: 360-361$.

Aoyagi A, Nishikawa K, Saito H, Abe K (1994) Characterization of basic fibroblast growth factor-mediated acceleration of axonal branching in cultured rat hippocampal neurons. Brain Res 661:117-126.

Armstrong J, McIntyre D, Neubort S, Sloviter R (1993) Learning and menory after adrenalectomy-induced hippocampal dentate granule cell degeneration in the rat. Hippocampus 3:359-371.

Ballarin M, Ernfors P, Lindefors N, Persson H (1991) Hippocampal damage and kainic acid injection induce a rapid increase in mRNA for BDNF and NGF in the rat brain. Exp Neurol 114:35-43.

Banker G, Goslin K (1991) Culturing nerve cells. Cambridge: MIT.

Bengzon J, Kokaia Z, Ernfors P, Kokaia M, Leanza G, Nilsson OG, Persson H, Lindvall O (1993) Regulation of neurotrophin and trkA, trkB, and trkC tyrosine kinase receptor messenger RNA expression in kindling. Neuroscience 53:433-446.

Boss B, Gozes I, Cowan W (1987) The survival of dentate gyrus neurons in dissociated culture. Dev Brain Res 36:199 218.

Brewer G, Torricelli J, Evege E, Price P (1993) Optimized survival of hippocampal neurons in B27-supplemented Neurobasal, a new serumfree Inediun conbinationl. J Neurusci Res 35:567-576.

Collazo D, Takahashi H, McKay RDG (1992) Cellular targets and trophic functions of neurotrophin-3 in developing rat hippocampus. Neuron 9:643-656.

Conrad C, Roy D (1993) Selective loss of hippocampal granule cells following adrenalectomy: implications for spatial memory. J Neurosci 13:2582-2590.

Cronin J, Dudek F (1988) Chronic seizures and collateral sprouting of dentate mossy fibers after kainic acid treatment in rats. Brain Res 474:181-184.

Cronin J, Obenaus A, Houser C, Dudek F (1992) Electrophysiology of dentate granule cells after kainate-induced synaptic reorganization of the mossy fibers. Brain Res 573:305-310.

Dugich-Djordjevic M, Tocco G, Lapchak P, Pasinetti G, Najm I, Baudry M, Hefti F (1992a) Regionally specific and rapid increases in brainderived neurotrophic factor messenger RNA in adult rat brain following seizures induced by systemic administration of kainic acid. Neuroscience 47:303-315.

Dugich-Djordjevic M, Tocco G, Willoughby D, Najm I, Pasinetti G, Thompson R, Baudry M, Lapchak P, Hefti F (1992b) BDNF mRNA expression in the developing rat brain following kainic acid-induced seizure activity. Neuron 8:1127-1138.

Dugich-Djordjevic M, Ohsawa F, Hefti F (1993) Transient elevation in catalytic trkB mRNA during postnatal development of the rat brain. NeuroReport 4:1091-1094.

Eckenstein F, Kuzis K, Nishi R, Woodward W, Meshul C, Sherman L, Ciment G (1994) Cellular distribution, subcellular localization and possible functions of basic and acidic fibroblast growth factors. Biochem Pharmacol 47:103-110.

Eide F, Lowenstein D, Reichardt L (1993) Neurotrophins and their receptors: current concepts and implications for neurologic disease. Exp Neurol 121:200-214.

Ernfors P, Bengzon J, Kokaia Z, Persson H, Lindvall O (1991) Increased levels of messenger RNAs for neutrophic factors in the brain during kindling epileptogenesis. Neuron 7:165-176.

Fayein N, Courtois Y, Jeanny J (1992) Basic fibroblast growth factor high and low affinity binding sitcs in dcveloping mousc brain, hippocampus and cerebellum. Biol Cell 76:1-13.

Franck J, Pokorny J, Kunkel D, Schwartzkroin P (1995) Physiologic and morphologic characteristics of granule cell circuitry in human epileptic hippocampus. Epilepsia 36:543-558.

Frotscher M, Zimmer J (1983) Lesion-induced mossy fibers to the molecular layer of the rat fascia dentata: identification of postsynaptic granule cells by the Golgi-EM technique. J Comp Neurol 215:299-311. Glass DJ, Nye SH, Hantzopoulos P, Macchi M, Squinto SP, Goldfarb M, Yancopoulos GD (1991) TrkB mediates BDNF/NT-3 dependent survival and proliferation in fibroblasts lacking the low affinity NGF receptor. Cell $66: 405-413$.

Gomez R, Pozzo Miller L, Aoki A, Ramirez O (1990) Long-term potentiation-induced synaptic changes in hippocampal dentate gyrus of rats with an inborn low or high learning capacity. Brain Res 537:293-297.

Gomez-Pinilla F, Lee J, Cotman C (1992) Basic FGF in adult brain: cellular distribution and response to entorhinal lesion and fimbriafornix transection. J Neurosci 12:345-355.

Gomez-Pinilla F, Lee J, Cotman C (1994) Distribution of basic fibroblast growth factor in the developing rat brain. Neuroscience 61:911-923.

Gould E, Wooley C, McEwen B (1990) Short-term glucocorticoid manipulations affect neuronal morphology and survival in the adult dentate gyrus. Neuroscience 37:367-375.

Holtzman D, Lowenstein D (1995) Selective inhibition of axon outgrowth by antibodies to NGF in a model of temporal lobe epilepsy. J Neurosci 15:7062-7070.

Ip N, Li Y, Yancopoulos G, Lindsay R (1993) Cultured hippocampal neurons show responses to BDNF, NT-3 and NT-4, but not NGF. J Neurosci 13:3394-3405.

Isackson PJ, Murray K, Huntsman M, Gall CM (1991) BDNF mRNA expression is increased in adult rat forebrain after limbic seizures: temporal patterns of induction distinct from NGF. Neuron 6:937-948.

Isokawa M, Levesque M, Babb T, Engel J (1993) Single mossy fiber axonal systems of human dentate granule cells studies in hippocampal slices from patients with temporal lobe epilepsy. J Neurosci 13:1511-1522.

Kase H, Iwahashi K, Nakanishi S, Matsuda Y (1987) K-252 compounds, novel and potent inhibitors of protein kinase $\mathrm{C}$ and cyclic nucleotidedependent kinases. Biochem Biophys Res Commun 142:436-440.

Klein R, Nanduri V, Jing SA, Lamballe F, Tapley P, Bryant S, CordonCardo C, Jones KR, Reichardt LF, Barbacid M (1991) The trkB tyrosine protein kinase is a receptor for brain-derived neurotrophic factor and neurotrophin-3. Cell 66:395-403.

Knusel B, Rabin S, Hefti F, Kaplan DR (1994) Regulated neurotrophin receptor responsiveness during neuronal migration and early differentiation. J Neurosci 14:1542-1554.

Laurberg S, Zimmer J (1981) Lesion-induced sprouting of mossy fiber collaterals to the fascia dentata in developing and adult rats. J Comp Neurol 200:433-459.

Lauterborn J, Isackson P, Gall C (1994) Seizure-induced increases in NGF mRNA exhibit different time courses across forebrain regions and are biphasic in hippocampus. Exp Neurol 125:22-40.

Louis J, Magal E, Gerdes W, Seifert W (1993) Survival-promoting and protein kinase $\mathrm{C}$-regulating roles of basic fgf for hippocampal neurons exposed to phorbol ester, glutamate and ischaemia-like conditions. Eur J Neurosci 5:1610-1621.

Lowenstein D, Seren M, Longo F (1993) Prolonged increases in neurotrophic activity associated with kainate-induced hippocampal synaptic reorganization. Neuroscience 56:597-604.

Malenka R (1995) Synaptic plasticity in the hippocampus: LTP and LTD. Cell 78:535-538.

Malenka R, Nicoll R (1993) NMD A-receptor-dependent synaptic plasticity: multiple forms and mechanisms. Trends Neurosci 16:521-527. 
Mattson M, Murrain M, Guthrie P, Kater S (1989) Fibroblast growth factor and glutamate: opposing roles in the generation and degeneration of hippocampal neuroarchitecture. J Neurosci 9:3728-3740.

Mattson M, Zhang Y, Bose S (1993) Growth factors prevent mitochondrial dysfunction, loss of calcium homeostasis, and cell injury, but not ATP depletion in hippocampal neurons deprived of glucose. Exp Neurol 121:1-13.

Mello L, Cavalheiro E, Tan A, Kupfer W, Pretorius J, Babb T, Finch D (1993) Circuit mechanisms of seizures in the pilocarpine model of chronic epilepsy: cell loss and mossy fiber sprouting. Epilepsia 34:985-995.

Miyagawa T, Saito H, Nishiyama N (1993) Branching enhancement by basic fibroblast growth factor in cut neurite of hippocampal neurons. Neurosci Lett 153:29-31.

Nishi M, Ueda S, Morita N, Kawata M (1994) Effects of glucocorticoid on neurones of rat dentate gyrus in dissociated culture. NeuroReport $5: 2446-2448$.

Shelton D, Sutherland J, Gripp J, Camerato T, Armanini M, Phillips H, Carroll K, Spencer S, Levinson A (1995) Human trks: molecular cloning, tissue distribution, and expression of extracellular domain immunoadhesins. J Neurosci 15:477-491.

Sloviter R (1992) Possible functional consequences of synaptic reorganization in the dentate gyrus of kainate-treated rats. Neurosci Lett 137:91-96.

Sloviter R, Valiquette G, Abrams G, Ronk E, Sollas A, Paul L, Neubort $S$ (1989) Selective loss of hippocampal granule cells in the mature rat brain after adrenalectomy. Science 243:535-538.
Soppet D, Escandon E, Maragos J, Middlemas DS, Reid SW, Blair J, Burton LE, Stanton BR, Kaplan DR, Hunter T, Nikolics K, Parada LF (1991) The neurotrophic factors brain-derived neurotrophic factor and neurotrophin-3 are ligands for the $t r k \mathrm{~B}$ tyrosine kinase receptor. Cell 65:895-903.

Squinto SP, Stitt TN, Aldrich TH, Davis S, Bianco SM, Radziejewski C, Glass DJ, Masiakowski P, Furth ME, Valenzuela DM, Distefano PS, Yancopoulos GD (1991) trkB encodes a functional receptor for brainderived neurotrophic factor and neurotrophin-3 but not nerve growth factor. Cell 65:885-893.

Sutula T, Xiao-Xian H, Cavazos J, Scott G (1988) Synaptic reorganization in the hippocampus induced by abnormal functional activity. Science 239:1147-1150.

Tauck D, Nadler J (1985) Evidence of functional mossy fiber sprouting in hippocampal formation of kainic acid-treated rats. $J$ Neurosci 5:1016-1022.

Vaher P, Luine V, Gould E, McEwen B (1994) Effects of adrenalectomy on spatial memory performance and dentate gyrus morphology. Brain Res 656:71-78.

Van der Zee C, Rashid K, Le K, Moore K, Stanisz J, Diamond J, Racine R, Fahnestock M (1995) Intraventricular administration of antibodies to nerve growth factor retards kindling and blocks mossy fiber sprouting in adult rats. J Neurosci 15:5316-5323.

Yazaki N, Hosoi Y, Kawabata K, Miyake A, Minami M, Satoh M, Ohta M, Kawasaki T, Itoh N (1994) Differential expression patterns of mRNAs for members of the fibroblast growth factor receptor family, FGFR-1FGFR-4, in rat brain. J Neurosci Res 37:445-452. 